\section{India embarks on push to become a solar power}

India's prime minister Manmohan Singh has unveiled a 30-year, US\$19-billion plan to make the country a leader in solar energy.

Announced on 3 August, the programme aims to raise installed solar capacity from its current $5 \mathrm{MW}$ to $20 \mathrm{GW}$ by $2020,100 \mathrm{GW}$ by 2030 and $200 \mathrm{GW}$ by 2050 , although a detailed road map has been drawn up to 2020 only. An autonomous solar-energy authority will be created to execute the mission, and the existing solar-energy centre near New Delhi will be upgraded to an institute that will coordinate solar-research centres across the country and promote foreign collaboration - a key feature of the plan.

Industry carrots include tax credits and priority bank loans for solar-power projects, as well as the duty-free import of raw materials. And conventional power plants with steam-driven turbines will have to generate at least $5 \%$ of their capacity from solar power.

For a longer version of this story, see http://tiny.cc/iem9|

\section{Lab worker charged with destroying protein crystals}

A former employee who allegedly destroyed US $\$ 500,000$ worth of protein crystal samples at the SLAC National Accelerator Laboratory in Menlo Park, California, was arrested and charged last week with wilfully ruining government property.

Silvya Oommachen, until July a research associate at SLAC's Joint Center for Structural Genomics (JCSG), removed $4,000-5,000$ protein crystals from three SLAC freezers at some point between 17 and 20 July, according to an FBI affidavit.

The now-useless crystals formed part of the Protein Structure Initiative, a federally funded project to expedite the discovery of atomic-level protein structures. JCSG director Ian Wilson estimates that his research team now faces a "two- to threemonth setback" to remake the protein crystals that had not yet been analysed. For a longer version of this story, see http://tinyurl.com/Ifnj43

\section{Plummeting silicon prices may boost solar sales}

The price of silicon for the solar-power industry has plunged in the past year as a result of increasing supplies and a sharp drop in demand, with the price of silicon photovoltaic panels poised to follow.

The spot price of solar-grade silicon — for immediate delivery - has fallen by roughly $77 \%$, from an average of more than US $\$ 300$ per kilogram last year to $\$ 67$ per kilogram today, according to the Londonbased consultancy New Energy Finance (see graph).

That has forced silicon and wafer suppliers to renegotiate contracts signed last year for delivery this year. Contracts signed at $\$ 150$ per kilogram have been cancelled or renegotiated at roughly $50 \%$ discount.

Even before the global financial crisis, analysts had warned that supplies would outstrip demand in 2009, with new

\title{
Chikyu showcases riser drilling for deep-sea research
}

\section{The first scientific ocean-floor drilling project to use a riser drill - equipment previously used in oil exploration - was completed last week. \\ The Japanese research vessel Chikyu (pictured) drilled 1,600 metres below the sea floor of the Nankai Trough, an earthquake-generating zone off the Pacific coast of Japan. \\ Riser drilling circulates mud in an extra casing around the drill to} prevent the collapse of a borehole in deep, high-pressure zones. Chikyu had already tested its riser-drilling equipment while on loan to an Australian oil company (see Nature 442, 964; 2006).

The vessel is taking a leading role in the Integrated Ocean Drilling Program, a collaboration of Japanese, US and European scientists studying rock and sediment samples to learn about Earth's structure and history. It is due to drill two more sites in the Nankai Trough.

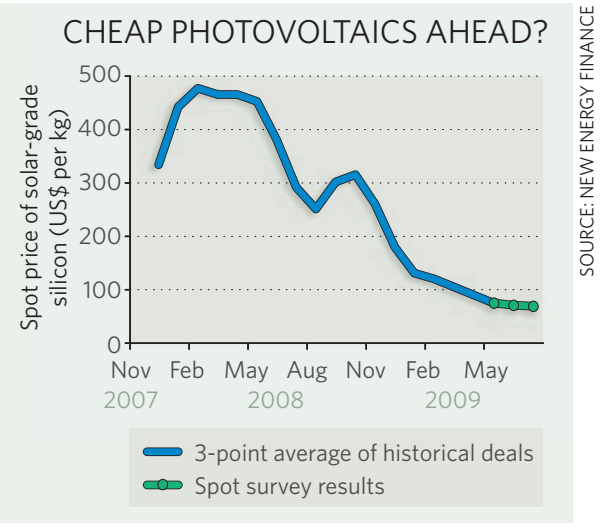

manufacturing facilities coming online at a time when countries such as Spain are scaling back solar subsidies. The good news for solar manufacturers, the consultancy reports, is that they should be able to halve the price of panels, which should spur demand.

\section{US report backs distinction between science and policy}

In setting regulatory policy, the US government should do more to separate scientific advice from policy decisions based on that advice, according to a report released on 5 August by the Bipartisan Policy Center, a non-profit body based in Washington DC established by former Democratic and Republican members of Congress.

The report recommends that regulatory agencies should post public notices that distinguish between the science and policy questions being asked. In appointing scientific advisory panels, agencies should adopt more stringent requirements about financial and professional conflicts of interest, and should be more transparent in disclosing them, it says. The report has been reviewed by the administration of President Barack Obama, who condemned the politicization of science in March, and is expected to issue guidelines on these issues later this year.

\section{Corrections}

The News story 'Biodefence lab criticized' (Nature 460, 556-557; 2009) conflated two different foot-and-mouth disease outbreaks in Britain. The 2001 outbreak required the slaughter of 6 million animals; a 2007 outbreak originated from the animal-research lab in Pirbright.

The News story 'Flu jabs urged for developing countries' (Nature 460, 156-157; 2009) incorrectly stated that Abdullah Brooks has determined that one-third of pneumonia deaths in children younger than 2 years old in Bangladesh can be attributed to the influenza virus. In fact, he has determined that about one-third of children who get influenza develop pneumonia, of whom about two-thirds are less than two years old. 